\title{
Prediction of Type A behaviour: A structural equation model
}

\begin{abstract}
Authors:
René van $W_{y k}{ }^{1}$

André B. Boshoff ${ }^{1}$

Gideon Nieman ${ }^{1}$

Jurie van Vuuren $^{1}$

Marius Pretorius ${ }^{1}$
\end{abstract}

\section{Affiliations: \\ ${ }^{1}$ Department of Business Management, University of Pretoria, South Africa}

\section{Correspondence to:}

René van Wyk

e-mail:

rene.vanwyk@up.ac.za

\section{Postal address:}

Department of Business Management, Faculty

of Economic and Management Sciences, University of Pretoria, 0002, Pretoria, South Africa

\section{Keywords:}

coronary-prone

behaviour; stress-linked

disease; locus of control;

Type A behaviour;

structural equation model

\section{Dates:}

Received: 14 Oct. 2008

Accepted: 16 Oct. 2008

Published: 07 May 2009

How to cite this article: Van Wyk, R., Boshoff, A.B., Nieman, G., Van Vuuren, J., \& Pretorius, M. (2009). Prediction of type A behaviour: A structural equation model. $S A$ Journal of Industrial Psychology/SA Tydskrif vir Bedryfsielkunde, 35(1), Art. \#758, 9 pages. DOI: 10.4102/sajip.v35i1.758

This article is available at: http://www.sajip.co.za

(C) 2009. The Authors. Licensee: OpenJournals Publishing. This work is licensed under the Creative Commons Attribution License.

\section{ABSTRACT}

The predictability of Type A behaviour was measured in a sample of 375 professionals with a shortened version of the Jenkins Activity Survey (JAS). Two structural equation models were constructed with the Type A behaviour achievement sub-scale and global (total) Type A as the predictor variables. The indices showed a reasonable-to-promising fit with the data. Type A achievement was reasonably predicted by service-career orientation, internal locus of control, power self-concept and economic innovation. Type A global was also predicted by internal locus of control, power self-concept and the entrepreneurial attitude of achievement and personal control.

\section{INTRODUCTION}

The cardiology researchers Friedman and Rosenman (1959) coined the concept of Type A behaviour when they discovered a typical behaviour pattern in most cardiology patients, namely an intense drive towards (1) poorly defined goals, (2) competitiveness, (3) persistence in the pursuit of advancement and recognition, (4) involvement in multiple tasks, (5) working at an accelerated mental and physical rate and (6) high physical alertness.

Since the identification of Type A behaviour by Friedman and Rosenman (1959), inconsistent results have been reported concerning the relationship between Type A behaviour and coronary heart disease (CHD) (Catipovic, Glavas, Kristek \& Sram, 2001; Denollet, 2004).

\section{Opposing views on Type A}

On the one hand, there is some evidence that Type A behaviour is not really very toxic and that it does not necessarily lead to CHD (Ben-Zur, 2002; Dembroski \& Costa, 1988; Dembroski, MacDougall, Costa \& Grandits, 1989; Haynes \& Matthews, 1988; Huysamen, 1994; Lutz, Holmes \& Cramer 1987; Williams, Barefoot, Haney \& Harrell, 1988).

On the other hand, sufficient evidence indicates that Type A behaviour should not be ignored, owing to its significant relationships with various physical and psychological symptoms, such as:

- CHD (Del Pino Perez, Meizoso \& Gonzalez, 1999; Gallacher, Sweetnam, Yarnell, Elwood \& Stansfeld, 2003; Jin-Fu, De-Sen \& Shui-Yuan, 2005; Sehgal, 2000), such as a modest increase in coronary stenosis (Yoshimasu et al., 2000), high cardiac reactivity with slow recovery (Palmero, Diez \& Asensio, 2001), elevated systolic and diastolic blood pressure (Omura, Saito \& Sasaki, 2005, atherosclerosis (Suls \& Sanders, 1989) and hypertension (Yan et al., 2003).

- Deterioration of health (Birks \& Roger, 2000; Jamal, 2005; Jamal \& Baba, 2003; Sumi, 1998), for instance: burn-out (Idemudia, Jegede, Madu \& Arowola, 2000; Jamal, 2005; Jamal \& Baba, 2001; Law, 2004), upper respiratory-tract infections (Stout \& Bloom, 1982), stress-linked diseases (Hicks, Lingen \& Eastman, 1979; Hicks \& Pellegrini, 1982), sleep problems (Hicks \& Pellegrini, 1982), headaches (Hicks \& Campbell, 1983; Martin, Nathan \& Milech, 1987), migraines (Rapport, McAnulty \& Brantley, 1988), duodenal-ulcer symptoms (Ayzenberg, 1983), stomach disorders (Hicks \& Pellegrini, 1982), ischaemic stroke (Kim et al., 1998), work-related problems such as high work involvement and workaholism (Roodt, Bester \& Boshoff, 1994), workplace aggression (Baron, Neuman \& Geddes, 1999), and psychiatric sick-leave (Moriana \& Herruzo, 2005).

- Negative psychological symptoms (Nakano \& Kitamura, 2002; Sumi, 1998), hostility (Sebregts, Falger, Appels, Kester \& Bär, 2005), negative emotions (Fukunishi et al., 1992; Martin et al., 1987; Mellam \& Espnes, 2003) and accident prone behaviour (Suls \& Sanders, 1989).

- $\quad$ Reduced social support (Furchner, 1999; Jamal \& Baba, 2001; Sumi, 1998), an increased road-traffic accident risk (Nabi et al., 2005) and a significant positive relationship between Type A aggression and pessimism (Hasan, 2002), which, according to Seligman (1998), is the primal cause of learned helplessness leading to a decrease in psychological health.

Overall, it seems that Type A behaviour has a number of negative health effects.

\section{Possible reasons for differences in Type A relationships}

Gastorf and Teevan (1980) and Nowack (1987) explain differences in findings related to Type A behaviour as being due to reluctance by Type A individuals to report symptoms as a self-defensive pattern motivated by a fear of failure, by ignorance and by the suppression of somatic and psychological symptomatology. Inconsistencies could also relate to sampling methods (Strümpfer, 1993b). These differences in relationships in Type A behaviour are explained by Alkhadher (1999) as being due to the measurement of Type A as a global construct, whereas the separation of individual sub-constructs leads to some differentiation in relationships.

With the separation of the Type A sub-constructs, it seems that it is especially the Type A components of anger (Northam \& Bluen, 1994), achievement in interaction with high optimism (Begley, Lee \& Czajka, 2000), impatience (Nakano \& Kitamura, 2002; Siu, Cooper \& Leung, 2000), enthusiasm (Yoshimasu et al., 


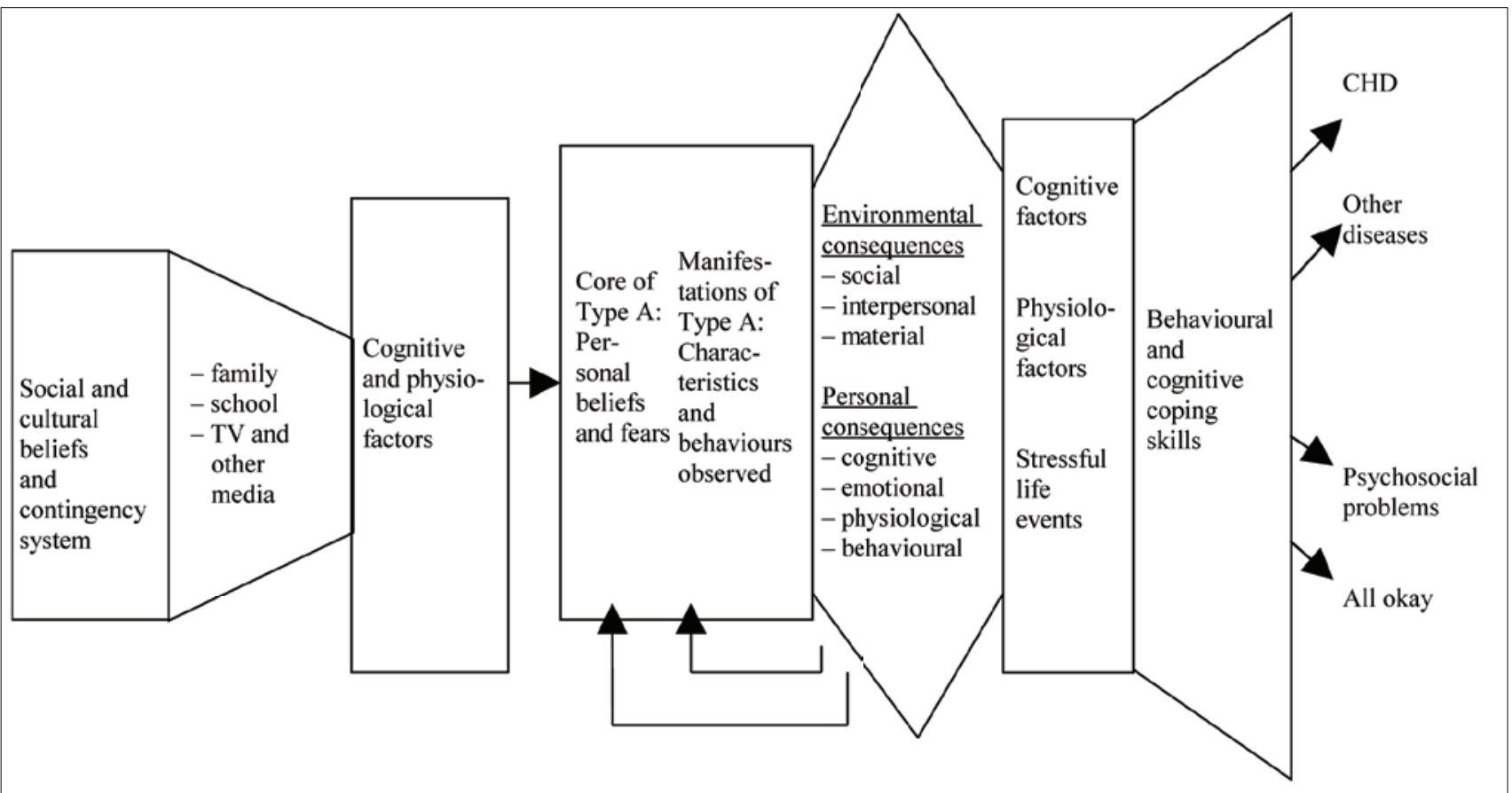

Proposed cognitive social-learning model of the Type A behaviour pattern (Price, 1982, p. 38)

2001), competitiveness (Furchner, 1999; Yoshimasu et al., 2001), enthusiasm and competitiveness (Yoshimasu et al., 2002) and hostility (Furchner, 1999; Williams, Barefoot \& Schneiderman, 2003), as well as the social isolation caused by this behaviour (Furchner, 1999; Jamal \& Baba, 2001) that relate to the severity of coronary atherosclerosis and other health risks. Although Type A achievement did not relate to burn-out in a sample of 329 Swedish information-communication technology consultants, burn-out significantly related to the irritability and impatience construct of Type A behaviour (Hallberg, Johansson \& Schaufeli, 2007).

\section{Opposing views on advanced performance due to Type A behaviour}

Notwithstanding this negative view of Type A behaviour, some profitable outcomes do relate to this behaviour pattern: Type As are seen as having a heightened sense of self-efficacy, mastery and personal competence (Bryant \& Yarnold, 1991). Although Strümpfer (1980) argues that Type A behaviour does not necessarily equal occupational and educational competency, there is some evidence indicating that Type As are significantly higher performers than Type Bs (Bryant \& Yarnold, 1991; Roskies, 1987). There are, however, some inconsistencies concerning the performance of Type A individuals compared with that of Type Bs. Keinan and Koren (2002) argue that the contradictions in some findings indicating that Type As do not perform significantly better than Type Bs may be due to differences in the challenges presented in the research design. A study comparing the performance of Types A and B indicates that teams consisting mainly of Type A were consistently more productive than their Type B team counterparts when performing both competitive and non-competitive tasks (Keinan \& Koren, 2002).

\section{Therapeutic intervention in the Type A behaviour pattern}

Although Type A achievement and global behaviour seem to be rewarding for some professionals as things seem to get done through achievement and through hard driving and competitiveness, the negative health indications related to this behaviour pattern should not be ignored, since treatment seems to achieve a definite decline in the occurrence of coronary blockage (MacLennan, 1994) and notable statistical and clinical reductions in the recurrence of myocardial infarction (Friedman \& Thoresen, 2001; Thoresen, Friedman, Powell, Gill \& Ulmer, 1987). Type As should be made aware that typical Type A behaviour is not a prerequisite for occupational and educational achievement and that similar successful accomplishments are achieved by Type Bs (Strümpfer, 1980). Type As should be further sensitised to the fact that the negative health consequences associated with Type A behaviour outweigh the superficial attractiveness of this kind of behaviour (Kirkcaldy, Shephard \& Furnham, 2002), which is especially prevalent in managerial positions in South Africa (Strümpfer, 1993a). It is therefore argued that therapeutic intervention for even healthy Type A behaviour is ethically justified.

Roskies (1987) declares that the provision of new and better ways of coping with daily irritations the everyday hassles of life should be the purpose of stress-management training for healthy Type A behaviour. She proposes that the aim of treatment for healthy Type A behaviour should be to reduce stress-related factors by increasing the individual's awareness and control of her or his perceptions of and reactions to stress. The individual can therefore become more skilled in pursuing personal goals with a minimum cost in terms of personal upset and disruption in interpersonal relations.

According to MacLennan (1994), a prerequisite for successful intervention in Type A behaviour is the ability to grow in self-knowledge. She states that intervention itself leads to an increase in congruency and thus psychological-mindedness. Type A individuals should be taught to adopt healthier behaviour patterns with similarly successful outcomes (Price, 1982). Meaningful intervention should be aimed at helping individuals live active, productive lives without paying a price in terms of physical tension, mental turmoil and disturbed relations with others (Roskies, 1990). The high stress levels caused by Type A behaviour can be moderated through exercise, as indicated in a study by Siu et al. (2000) among Hong Kong managers, provided that individuals do not see exercise situations as competitive, which could lead to further negative effects of anger, depression and anxiety (Masters, Lacaille \& Shearer, 2003). 
Taking into account the high prevalence of Jenkins Activity Survey (JAS) Type A behaviour measured in South Africa (Strümpfer, 1993a), it is important that management make employees aware that Type A behaviour can be detrimental to their health and that preventive actions can be taken. Psychological distress, measured by the Hopkins Symptoms Checklist: HSCL-10, for example, is significantly higher among men with Type A behaviour than among men without Type A behaviour at the 95\% confidence interval (Søgaard, Dalgard, Holme, Røysamb \& Håheim, 2008). Employers can enhance the overall well-being of employees who have been identified as displaying Type A behaviour through stress management (Idemudia et al., 2000). The presence of reactive systolic and diastolic blood pressure in Type A individuals, for example, can be effectively decreased through training and intervention, moderating their typical excessive cardiovascular responses (Dion, Gerrard, Ready \& Dyck, 1992; Omura et al., 2005) and the cognitive aspects of Type A, in particular the conduct of hostility (Sebregts et al., 2005).

Ayzenberg (1983), however, warns that an attempt to change the Type A behaviour pattern might prove insufficient if the needs associated with the behaviour are not also addressed. Intervention focused on behaviour only is therefore only palliative, as the underlying personality structure is not addressed. She even believes that the modification of Type A behaviour without a change in core emotions could prove dangerous, as it does not allow the discharge of some emotional drives and denial thereof could have pathological effects.

Pace et al. (1986) propose an ecological approach to the treatment of Type A behaviour in the workplace, given that the syndrome arises from different intrapersonal, interpersonal, institutional and cultural sources. Treatment would include that of elements surrounding the system of the individual, namely the ecological system. For this reason and in the light of the argument by Byrne (2000) that it is the interaction between Type A behaviour and work circumstances that leads to health-risk factors, it is important to investigate the possible occupational variables that could lead to Type A behaviour.

\section{Variables in an occupational situation that seem to cause Type A behaviour}

It is important to notice that the classifications of Type A and B entities are not mutually exclusive - the one is not the counterpart of the other (Thoresen et al., 1987); it is possible for individuals to display both Type A and Type B behaviours to different degrees (Webster, 1994).

What, in fact, causes Type A behaviour? Price (1982) explains Type A behaviour on the basis of a cognitive social-learning model. She argues that Type A behaviour cannot be seen as a personality type but rather as a set of socially learned behavioural responses. Her argument is based on work by Friedman and Rosenman (1959; 1974), which indicates that Type A behaviour is produced and maintained in interaction with behavioural, environmental, cognitive and physiological factors, with certain antecedents and consequences enhancing or discouraging the maintenance of the behaviour pattern. The proposed cognitive social-learning theory model developed by Price (1982) is shown in Figure 1.

Williams et al. (2003) point out that there does not seem to be one single behavioural pathway that causes cardiovascular disease. Byrne (2000) expresses a concern that it could also be the interaction between Type A behaviour and occupational situations that leads to health-risk factors.

\section{Evidence of the prevalence of Type A behaviour in South Africa}

It seems important to explore predictive factors further, especially as there is some evidence to indicate a high tendency of Type A behaviour in South African organisations (Cox, 1983; Kahn, 1968; Strümpfer, 1980, 1990, 1993a, 1993b). This high prevalence of Type A in South African businesses suggests that cardiac disturbances can be predicted in both white and black South Africans (Els, 1987). The Type A tendency was also predominant in a sample of white South African students (Spangenberg, Shuda \& Robbertze, 1997).

This phenomenon can possibly be explained by the high demands that Western society makes in terms of individual achievement (Spangenberg et al., 1997) and personal performance in the work situation, which could lead to a high level of strain in professional activities (Byrne, 1987). The high occurrence of Type A could also be due to the shortage of highlevel human resources in South African business and industry (Strümpfer, 1990).

\section{Relationship between Type A behaviour and occupational variables}

Although research concerning the Type A concept has decreased in the last decade, this does not mean that all relationships have already been answered. It is for this reason that this study investigated the possible cognitive organisational factors that could cause Type A behaviour (as depicted in Price's model given in Figure 1). The cognitive organisational factors under investigation were the locus of control, career orientation, self-concept and entrepreneurial attitude of individuals.

The element of control seems to be an important characteristic of the Type A behaviour pattern (Benight \& Kinicki, 1988; Clark \& Miller, 1991; Glass, Snyder \& Hollis, 1974). It does, in fact, play an important role in emotional reactions that lead to tension or anxiety (Glass et al., 1974). Glass (1977) is of the opinion that a Type A behavioural style is activated when an individual's sense of control is threatened. Clark and Miller (1991) report that a desire for control potentially gives rise to anger, which is a component of the more 'toxic' Type A behaviour in terms of the development of coronary-artery disease. Many studies indicate generally weak associations between Type A behaviour and locus of control (Begley, 1995; Feather \& Volkmer, 1988; Furnham, 1983; Glass, 1977; Gomez, 1997; Morrison, 1997; Norden, 1995; Spector \& O'Connel, 1994; Wolf, Hunter, Webber \& Berenson, 1981). Kirkcaldy et al. (2002) demonstrate that an external locus of control in combination with Type A personality characteristics point towards significantly lower work satisfaction in a sample of 332 German managers.

Certain career orientations, as identified by the career anchors of Schein (1978), seem to be a further potential construct related to Type A behaviour. Studies by Burke $(1983,1985)$ identify a low but significant positive correlation between Type A behaviour (measured by JAS scores) and the career orientations (in terms of Schein, 1978) of self-investors and careerists and a significant negative correlation Type A behaviour and the career orientations of artisans (Jenkins, Zyzanski \& Rosenman, 1979).

According to Anastasi (1990), an individual's self-concept can be seen as the collective effect of self-evaluation on cognitive and emotional traits and as either directly or indirectly influencing the functioning of an individual. In studies by Wolf et al. (1981) and by Lobel (1988), the relationship between a positive selfconcept and Type A behaviour was found to be significantly negative.

Entrepreneurs are generally seen as achievers in society. At present, the study of entrepreneurship is attracting considerable attention. The relationship between Type A behaviour and entrepreneurial attitudes has not, as far as could be established, previously been studied and seems to be an important area for investigation (Van Wyk, 1998). 
It is not clear how the constructs of locus of control, career orientation, self-concept and entrepreneurial attitude as independent variables would predict the prevalence of Type A behaviour as the dependent variable in a structural-equation model. This study therefore conducted a comprehensive investigation into the predictability of different personality variables in combination with Type A behaviour in a sample of professionals.

The sample was selected from two occupational groups, namely accountants and pharmacists (Van Wyk \& Boshoff, 2004), as these professionals have an important role to play in symbolising service to society (Gamble \& Matteson, 1992; Schein \& Kommers, 1972). The public accounting and pharmaceutical professions are also seen as highly stressful occupations in terms of workload and role stressors, leading to job exhaustion in the case of accountants (Law, 2004).

The goal of this paper was to investigate the predictability of Type A behaviour through the personality constructs of locus of control, career orientation, self-concept and entrepreneurial attitude by means of structural-equation modelling.

\section{RESEARCH DESIGN}

\section{Research approach}

A non-experimental, cross-sectional survey was done on two professional groups with mutually exclusive profiles on the Holland Hexagon (Holland, 1985), namely pharmacists and accountants (Van Wyk \& Boshoff, 2004). Two probability sampling methods were used, namely stratified sampling (where members of a specific professional society were used) and systematic sampling (where the total professionals registered were divided by 60 and individuals were selected at given intervals) (Kerlinger \& Lee, 2000). Questionnaires were mailed to individuals, together with pre-addressed and pre-stamped return envelopes. Follow-up letters were sent one week later. The participants took part voluntarily and anonymously. The completed questionnaires were personally coded.

\section{Research method}

\section{Participants}

The sample consisted of 375 professionally registered pharmacists $(\mathrm{N}=200)$ and accountants $(\mathrm{N}=175)$. The mean age of the sample was 41.6 years $(\mathrm{SD}=12.46)$. The respondents spoke mainly Afrikaans $(\mathrm{N}=158)$ or English $(\mathrm{N}=211)$ as their home language, with a few speaking Tshivenda $(\mathrm{N}=1)$, isiZulu $(\mathrm{N}=2)$ and North Sotho $(\mathrm{N}=2)$.

The number of participants employed in organisations was $\mathrm{N}$ $=201(53.6 \%)$ and the number working as private practitioners was $\mathrm{N}=169(45.1 \%)$. Five participants did not indicate whether they were employees in someone else's company or working as private practitioners. The number of jobs held by the participants prior to this study varied between one and eight; $93 \%$ had held five or fewer jobs during their careers prior to this study. The number of years' work experience held by the respondents up to the time of this study varied between one and sixty; the mean number of years worked was 18.7 (SD = 12.56). The mean number of organisations worked at was 2.83 $(\mathrm{SD}=1.56)$ before participation in this study.

The majority of the participants $(\mathrm{N}=295$ or $78.7 \%)$ were married, 62 (16.5\%) were divorced, ten were widowed, six were cohabiting and two did not indicate their marital status. Most of the participants $(77.6 \%)$ grew up in an urban environment. The majority (56.8\%) of the participants grew up in the Gauteng province of South Africa, with a more or less even spread over the other eight provinces for the rest of the participants.

\section{Measuring instruments}

The demographic information that was gathered on the participants concerned their gender, occupation, home language, employment, marital status, area of birth, province of birth, age, number of jobs held, number of years worked and number of organisations to which they had been attached.

Because the primary purpose of this study was to determine the predictability of Type A behaviour, this construct was measured by means of a shortened form of the JAS as developed by Spence, Helmreich and Pred (1987). Exploratory factor analysis yielded three factors with rather low alpha coefficients for the three scales $(0.65,0.52$ and 0.49 respectively), possibly due to the low number of items. However, confirmatory factor analysis showed a satisfactory fit between the measurement model and the data, with a goodness-of-fit index (GFI) of 0.93, an adjusted GFI of 0.90 and a root mean-square error of approximation (RMSEA) estimate of 0.07 , which rendered the instrument acceptable. The three factors were 'achievement' (five items), 'hard driving/competitiveness' (four items) and 'speed/impatience' (three items).

The Locus of Control Instrument developed by Schepers (1995) was used to measure locus of control. Exploratory factor analysis led to a three-factor solution containing 38, 14 and 5 items respectively, with Cronbach alphas of $0.91,0.78$ and 0.84 respectively. These factors were 'internal locus of control', 'external locus of control' and 'vicissitudes of life'.

Career orientation was measured with the Career Orientations Inventory (Schein, 1995). The exploratory factor analysis on the responses of the sample indicated four identifiable factors, with Cronbach alpha coefficients of $0.86,0.81,0.80$ and 0.72 respectively. These factors were 'service dedication' (eleven items), 'job security' (five items), 'entrepreneurship' (five items) and 'lifestyle integration' (three items).

The six-factor Self-concept Scale of Stake (1994) was used to measure the self-concept of the participants. Exploratory factor analysis yielded a three-factor solution, with Cronbach alpha coefficients of $0.85,0.84$ and 0.84 respectively. The factors were identified as 'power' (14 items), 'task accomplishment' (12 items) and 'likeability' (6 items).

The Entrepreneurial Attitude Orientation Scale developed by Robinson, Stimpson, Huefner and Hunt (1991) was used to measure entrepreneurial attitude. A three-factor solution based on the responses was accepted for the exploratory factor analysis, which contained 29, 21 and 12 items respectively. The three factors were identified as 'attitude towards economic innovation', 'achievement/personal control' and 'self-esteem'. The Cronbach alphas were $0.90,0.80$ and 0.77 respectively.

\section{Procedure}

Random stratified sampling was done in two main economic areas of activity in South Africa (Gauteng and the Western Cape) on professionally registered pharmacists and accountants. A total of 418 completed questionnaires was received out of the 1 100 questionnaires distributed by mail in Gauteng and the 100 in the Western Cape. Questionnaires were left out of the analysis where any of the psychometric instruments had no response to one or more of the items. A total of 375 questionnaires was used in the final statistical analyses. The questionnaire consisted of biographical variables and questions measuring Type A behaviour, locus of control, career orientation, self-concept and entrepreneurial attitudes.

\section{Statistical analysis (analysis of data)}

Factor analysis was done on all the personality instruments to confirm construct validity and to limit error-variance measurements (Cavusgil \& Das, 1997). Principal factor analysis 
was performed with direct quartimin rotation, followed by confirmatory factor analysis that assessed the quality of fit between the measurement model and the data (Van Wyk, Boshoff \& Owen, 1999). Statistical analyses concerning the relationship between Type A scores and personality variables were investigated by means of Pearson product-moment correlation and multiple-regression analysis (Van Wyk, 1998; Van Wyk \& Boshoff, 2000).

\section{RESULTS}

On the grounds of the significant relationships indicated by the Pearson product-moment correlation and multiple-regression analysis of a previous study (Van Wyk \& Boshoff, 2000; Van Wyk, Boshoff \& Bester, 1999), two structural-equation models were investigated, with the prediction of achievement and global Type A as outcome variables. Structural-equation models were not built to predict hard driving and competitiveness, and speed and impatience, as these variables are not predicted well by means of multiple regression (Van Wyk \& Boshoff, 2000). The predictions of achievement and global Type $\mathrm{A}$ are illustrated in Figures 2 and 3. Confirmatory factor analysis was performed to evaluate the strength of the model fit, as indicated in Tables 1 and 2.

With the exception of the internal locus of control economic innovation path coefficients, as indicated in Figure 1 (a value of 0.16 ), the other coefficients are all satisfactory (above 0.30 ).

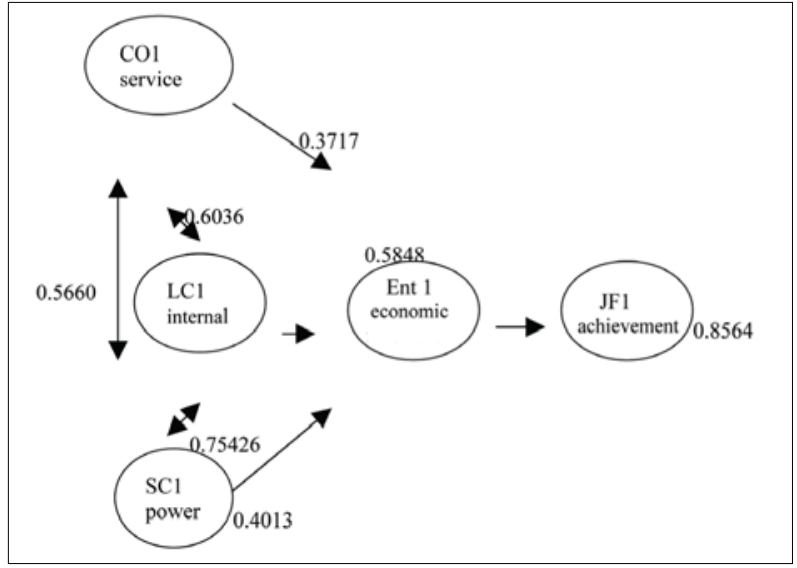

FIGURE 2

Structural equation Model 1 with Type A achievement as the outcome variable

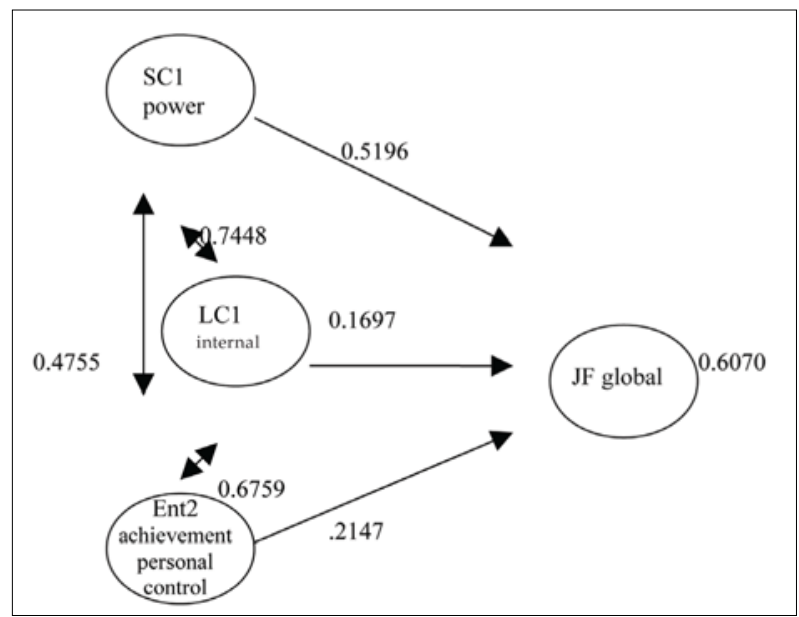

FIGURE 3

Structural equation Model 2 with global Type A behaviour as the outcome variable
Taking into account the values of the indices as indicated in Table 1, the causal model as shown in Figure 2 indicates a promising fit with the data according to the criteria set out by Hair, Anderson, Tatham and Black (1998). The basal metabolic rate (RMR) and RMSEA values are close to zero and the other relevant fit indices approach 1.0.

The path coefficients, given in Figure 3, are at an acceptable level, with the exception of the path coefficients between internal locus of control, Ent 2 and global Type A behaviour, which are below 0.3. Consequently, these causal relationships are low. The fit between the data and the model shown in Figure 3 is promising (Hair et al., 1998), with the RMR and RMSEA values approaching zero and the other relevant fit indices being around 0.9 .

\section{DISCUSSION}

The primary contribution of this study is the construction of a structural-equation model to determine the prediction of Type A achievement and global behaviour in two groups of professional people. The results indicate that Type A achievement and global behaviour can be explained by means of certain types of career orientation, locus of control, self-concept and entrepreneurial attitudinal variables, as measured in this study.

The study has broadened the view of causal relationships between different variables and Type A behaviour in the work environment. The structural-equation models indicate that different forms of self-perception - such as locus of control (internal), self-esteem (power) and individual service career orientation - were involved in the development of the entrepreneurial attitude of economic innovation and, finally, the maintenance of Type A achievement behaviour. The global prediction of Type A is indicated by means of the power selfconcept variable, internal locus of control and an achievement or personal-control entrepreneurial attitude. Seen in the light of the argument by Price (1982) that Type A is not a personality type but a set of socially learned behavioural responses, it is important for professionals in the pharmacy and accountancy

TABLE 1

Indices obtained from a structural-equation analysis of Model 1

\begin{tabular}{lc}
\hline INDICES & VALUE \\
\hline GFI & 0.8941 \\
GFI Adjusted for Degrees of Freedom (AGFI) & 0.8618 \\
Root Mean Square Residual (RMR) & 0.1777 \\
RAMSEA estimate (.0645-.0811) & 0.0728 \\
Chi-square (df = 131, p > Chi $\left.{ }^{2}<0.0001\right)$ & 390.4037 \\
Bentler's Comparative Fit Index & 0.9301 \\
Bentler \& Bonett's (1980) Non-normed Index & 0.9184 \\
Bentler \& Bonett's (1980) NFI & 0.8990 \\
Bollen (1986) Normed Index Rho1 & 0.8820 \\
Bollen (1988) Non-normed Index Delta2 & 0.9305 \\
\hline
\end{tabular}

TABLE 2

Indices obtained from a structural-equation analysis of Model $2(\mathrm{~N}=375)$

\begin{tabular}{lr}
\hline INDICES & VALUE \\
\hline GFI & 0.8961 \\
GFI Adjusted for Degrees of Freedom (AGFI) & 0.8630 \\
Root Mean Square Residual (RMR) & 0.1921 \\
RAMSEA estimate (.0658-.0834) & 0.0745 \\
Chi-square (df = 116, p > Chi $<0.0001)$ & 356.9361 \\
Bentler's Comparative Fit Index & 0.9136 \\
Bentler \& Bonett's (1980) Non-normed Index & 0.8987 \\
Bentler \& Bonett's (1980) NFI & 0.8780 \\
Bollen (1986) Normed Index Rho1 & 0.8569 \\
Bollen (1988) Non-normed Index Delta2 & 0.9142 \\
\hline
\end{tabular}


careers to be aware of the influence of the need for internal locus of control, power, service and economic innovation, which could lead to increased Type A achievement behaviour. Global Type A was found to be especially influenced by the need for power, internal locus of control and a career orientation of achievement and personal control.

These findings confirm the argument of Pace et al. (1986) that Type A behaviour in the workplace is the result of different intrapersonal, interpersonal, institutional and cultural sources and the concern of Byrne (2000) that it could be the interaction between Type A behaviour and occupational situations that leads to health-risk factors.

The results of this study can be used to help Type A individuals to grow in self-knowledge, suggested by MacLennan (1994) as a prerequisite for successful intervention in this behaviour pattern. The results shed more light on the occupational elements that lead to Type A behaviour, which can aid the treatment of this form of behaviour (Pace et al., 1986). Improved self-knowledge can empower Type A individuals to prevent or moderate their cardiovascular responses (Dion, Gerard, Ready \& Dyck, 1992; Omura et al., 2005). It is important, however, that the needs of Type A individuals be addressed, as pure treatment without concern for personal needs can prove insufficient (Ayzenberg, 1983).

\section{Limitations and direction for future research}

The study has clear limitations. It was done on individuals in only two professional categories and the findings can therefore not be generalised to other occupational groups. The results of the low-path coefficients in the prediction of global Type A indicate a modest causality (Figure 3 ) supported by fair indices (Table 2).

Future studies should be aimed at professionals other than accountants and pharmacists and at non-professional groups. A broader measure of Type A behaviour (measuring more variables) would provide a better picture of the causalities of the different factors of this phenomenon. An examination of different variables from the ones measured in the current study should also be undertaken.

Future research should be aimed not only at the identification of Type A factors and the causal factors leading to this selfdestructive behaviour pattern (accompanied by the health problems indicated) but also at the alleviation of this kind of behaviour and at finding more constructive and healthier ways to reach success without the self-destructive behavioural tendencies of Type A's.

Individuals such as professionals should be alerted to the detrimental effects of Type A behaviour and to the need for control and achievement at various psychological, physical and psycho-social levels. The identification of Type A behaviour should be aimed at helping people to unlearn cognitive social-learning patterns and to form new, healthier behaviour patterns of positive behaviour as advocated by post-modern psychologists, such as Seligman (1998).

\section{Conclusion}

Knowledge gained through the current study sheds more light on the occupational variables that precipitate Type A behaviour. As far as could be established, the prediction of Type A constructs by means of the complex interaction effects that structural-equation modelling allows has not been done before. The findings therefore make an important contribution to the theory of Type A behaviour, specifically in the work context, which can lead to certain damaging Type A characteristics. Identification of the variables can fine-tune intervention strategies that can give Type A individuals more insight into behaviour that precipitates health damage.

\section{REFERENCES}

Alkhadher, O. (1999). Association of Type A behavior and job performance in a sample of Kuwaiti workers. Psychological Reports, 85, 189-196.

Anastasi, A. (1990). Psychological testing. New York: Macmillan. Ayzenberg, A. (1983). The Type A behaviour pattern and its associated personality variables in CHD, ulcer, asthma, non-psychosomatic patients and healthy controls. Master's dissertation. Cape Town: University of Cape Town.

Baron, R.A., Neuman, J.H., \& Geddes, D. (1999). Social and personal determinants of workplace aggression: Evidence for the impact of perceived injustice and the Type A behavior pattern. Aggressive Behaviour, 25(4), 281-296.

Begley, T.M. (1995). Using founder status, age of firm, and company growth rate as the basis for distinguishing entrepreneurs from managers of smaller businesses. Journal of Business Venturing, 10(3), 249-263.

Begley, T.M., Lee, C., \& Czajka, J.M. (2000). The relationships of Type A behaviour and optimism with job performance and blood pressure. Journal of Business and Psychology, 15(2), 215-227.

Benight, C.C., \& Kinicki, A.J. (1988). Interaction of Type A behaviour and perceived controllability of stressors on stress outcomes. Journal of Vocational Behavior, 33(1), 50-62.

Ben-Zur, H. (2002). Associations of Type A behavior with the emotional traits of anger and curiosity. Anxiety, Stress and Coping: An International Journal, 15(1), 95-104.

Birks, Y., \& Roger, D. (2000). Identifying components of Type A behaviour: 'Toxic' and 'non-toxic' achieving. Personality and Individual Differences, 28(6), 1093-1105.

Bryant, F.B., \& Yarnold, P.R. (1991). The impact of Type A behavior on subjective life quality: Bad for the heart, good for the soul. In M.J. Strube (Ed.), Type A behavior (pp. 339379). Newbury Park: Sage.

Burke, R.J. (1983). Career orientations of Type A individuals. Psychological Reports, 53(3), 979-989.

Burke, R.J. (1985). Career orientations and Type A behavior in police officers. Psychological Reports, 57, 1239-1246.

Byrne, D.G. (1987). The behavioral management of the cardiac patient. Norwood: Abex.

Byrne, D.G. (2000). The frustration of success: Type A behavior, occupational stress and cardiovascular disease. In D.T. Kenny \& J.G. Carlson (Eds.), Stress and health: Research and clinical applications (pp. 441-437). Amsterdam: Harwood Academic.

Catipovic, V.K., Glavas, B., Kristek, J., \& Sram, M. (2001). Components of Type A behavior and two-year prognosis of patients with acute coronary syndrome. Psychological Reports, 89(3), 467-475.

Cavusgil, T.S., \& Das, A. (1997). Methodological issues in empirical cross-cultural research: A survey of the management literature and a framework. Management International Review, 37(1), 71-62.

Clark, L.K., \& Miller, S.M. (1991). Self-reliance and desire for control in the Type A behavior pattern. In M.J. Strube (Ed.), Type A behavior (pp. 375-388). Newbury Park: Sage.

Cox, J.J. (1983). Coronary-prone behaviour and its relationship to stress in a South African environment. Master's thesis. Johannesburg: University of the Witwatersrand.

Del Pino Perez, A., Meizoso, M.T.G., \& Gonzalez, R.D. (1999). Validity of the structured interview for the assessment of Type A behavior pattern. European Journal of Psychological Assessment, 15(1), 39-48.

Dembroski, T.M., \& Costa, P.T. (1988). Assessment of coronaryprone behavior: A current overview. Annals of Behavioral Medicine Psychology, 10(2), 60-63.

Dembroski, T.M., MacDougall, J.M., Costa, P.T., \& Grandits, G.A. (1989). Components of hostility as predictors of sudden death and myocardial infarction in the multiple risk factor intervention trial. Psychosomatic Medicine, 51(5), 514-522.

Denollet, J. (2004). Type D personality in perspective. Journal of Psychosomatic Research, 56(6), 184. 
Dion, P.R., Gerrard, J.M., Ready, A.E., \& Dyck, D.G. (1992). Aerobic fitness level (V-sub[0]-sub[2max]) moderates the increased cardiovascular function and basal thrombosis formation of young healthy Type A males. Behavioral Medicine, 18(1), 33-39.

Els, N.J.S. (1987). Gedragskorrelate van koronêre hartsiektes by swartes. Master's dissertation. Johannesburg: Rand Afrikaans University.

Feather, N.T., \& Volkmer, R.E. (1988). Preference for situations involving effort, time pressure, and feedback in relation to Type A behavior, locus of control and test anxiety. Journal of Personality and Social Psychology, 55(2), 266-271.

Friedman, M., \& Rosenman, R.H. (1959). Association of specific overt behavior pattern with blood and cardiovascular finding: Blood cholesterol level, blood clotting time, incidence of arcus senilis and clinical coronary artery disease. Journal of American Medical Association, 169(12), 1286-1296.

Friedman, M., \& Rosenman, R.H. (1974). Type A behavior and your heart. New York: Knopf.

Friedman, M., \& Thoresen, C. (2001). Alteration of Type A behavior and its effect on cardiac recurrences in post myocardial infarction. Advances in Mind-Body Medicine, $17(1), 2-59$.

Fukunishi, E., Hattori, M., Hattori, H., Imai, Y., Miyake, Y., Miguchi, M., \& Yoshimatsu, K. (1992). Japanese Type A behavior pattern is associated with typus melancholicus: A study from the sociocultural viewpoint. The International Journal of Social Psychiatry, 38(4), 251-256.

Furchner, A.L. (1999). Type A behavior pattern and social support. Dissertation Abstracts International: Section B: The Sciences and Engineering, 59(9-B), 5064.

Furnham, A. (1983). The A Type behaviour pattern, mental health and health locus of control beliefs. Social Science and Medicine, 17(20), 1569-1572.

Gallacher, J.E.J., Sweetnam, P.M., Yarnell, J.W.G., Elwood, P.C., \& Stansfeld, S.A. (2003). Is Type A behavior really a trigger for coronary heart disease events? Psychosomatic Medicine, 65(3), 339-346.

Gamble, G.O., \& Matteson, M.T. (1992). Type A behavior, job satisfaction and stress among black professionals. Psychological Reports, 70, 43-50.

Gastorf, J.W., \& Teevan, R.C. (1980). The Type A coronary-prone behavior pattern and fear of failure. Motivation and Emotion, $4(1), 71-76$.

Glass, D.C. (1977). Behavior patterns, stress, and coronary heart disease. Hillsdale: Lawrence Erlbaum.

Glass, D.C., Snyder, M.L., \& Hollis, J.F. (1974). Time urgency and the Type A coronary-prone behavior pattern. Journal of Applied Social Psychology, 4(2), 125-140.

Gomez, R. (1997). Locus of control and Type A behavior pattern as predictors of coping styles among adolescents. Personality and Individual Differences, 23(3), 391-398.

Hair, J.F., Anderson, R.E., Tatham, R.L., \& Black, W.C. (1998). Multivariate data analysis (5th edn.). London: Prentice Hall.

Hallberg, U.E., Johansson, G., \& Schaufeli, W.B. (2007). Type A behaviour and work situation: Associations with burnout and work engagement. Scandinavian Journal of Psychology, 48(2), 135-142.

Hasan, H.J.T.M. (2002). Relations of the Arabic Type: A behavior scale with measures of optimism and pessimism. Psychological Reports, 91(3,Pt2), 1043-1051.

Haynes, S.G., \& Matthews, K.A. (1988). The association of Type A behavior with cardiovascular disease: Update and critical review. In: B.K. Houston \& C.R. Snyder (Eds.), Type A behavior pattern: Research, theory and intervention (pp. 51-82). New York: John Wiley.

Hicks, R.A., \& Campbell, J. (1983). Type A-B behavior and selfestimates of the frequency of headaches in college students. Psychological Reports, 52(3), 912.

Hicks, R.A., Lingen, S., \& Eastman, P.C. (1979). Habitual variable sleep and Type A behavior. Bulletin of the Psychonomic Society, 14(6), 469-470.
Hicks, R.A., \& Pellegrini, R.J. (1982). Sleep problems and Type A-B behavior in college students. Psychological Reports, 51(1), 196.

Holland, J.L. (1985). Making vocational choices: A theory of vocational personalities and work environments. (2nd edn.). Englewood Cliffs: Prentice Hall.

Huysamen, G.K. (1994). Die rol van Tipe-A-gedrag en sigaretrook by die voorspelling van koronêre hartsiektes. Suid-Afrikaanse Tydskrif vir Sielkunde, 24(2), 62-68.

Idemudia, S.E., Jegede, A.S., Madu, N.S., \& Arowola, F. (2000). Type A behaviour and burnout among bank managers in Nigeria. Journal of Psychology in Africa South of the Sahara, the Caribbean and Afro Latin America, 10(2), 189-196.

Jamal, M. (2005). Personal and organizational outcomes related to job stress and Type-A behavior: A study of Canadian and Chinese employees and health. Journal of the International Society for the Investigation of Stress, 21(2), 129-137.

Jamal, M., \& Baba, V.V. (2001). Type A behavior, job performance, and well-being in college teachers. International Journal of Stress Management, 8(3), 231-240.

Jamal, M., \& Baba, V.V. (2003). Type A behavior, components, and outcomes: A study of Canadian employees. International Journal of Stress Management, 10(1), 39-50.

Jenkins, C.D., Zyzanski, S.J., \& Rosenman, R.H. (1979). Jenkins activity survey: JAS manual. New York: The Psychological Corporation.

Jin-Fu, Z., De-Sen, Y., \& Shui-Yuan, X. (2005). The relationship between behavior types and plasminogen activation system in patients with coronary heart disease. Chinese Mental Health Journal, 19(4), 237-239.

Kahn, S.R. (1968). The role of anger in managerial effectiveness. Master's dissertation. Cape Town: University of Cape Town.

Keinan, G., \& Koren, M. (2002). Teaming up Type As and Bs: The effects of group composition on performance and satisfaction. Applied Psychology: An International Review, 51(3), 425-445.

Kerlinger, F.N., \& Lee, H.B. (2000). Foundations of behavioral research. (4th edn.). London: Harcourt.

Kim, J.S., Yoon, S.S., Lee, S.I., Yoo, H.J., Kim, C.Y., Choi-Kwon, S., \& Lee, B.C. (1998). Type A behavior and stroke: High tenseness dimension may be a risk factor for cerebral infarction. European Neurology, 39(3), 168-173.

Kirkcaldy, B.D., Shephard, R.J., \& Furnham, A.F. (2002). The influence of Type A behavior and locus of control upon job satisfaction and occupational health. Personality and Individual Differences, 33(8), 1361-1371.

Law, D.W. (2004). An examination of personality traits as moderating factors of exhaustion in public accounting. Dissertation Abstracts International Section A: Humanities and Social Sciences, 64(7-A), 2549.

Lobel, T.E. (1988). Personality correlates of Type A coronaryprone behavior. Journal of Personality Assessment, 52(3), 434440.

Lutz, D.J., Holmes, D.S., \& Cramer, R.E. (1987). Hard-driving and speed-impatience components of the Type A behavior pattern as predictors of physiological arousal, subjective arousal and challenge seeking. Journal of Psychosomatic Research, 31(6), 713-722.

MacLennan, N. (1994). Psychological mindedness and Type A behaviour change in coronary heart disease. Master's dissertation. Johannesburg: Rand Afrikaans University.

Martin, P.R., Nathan, P.R., \& Milech, D. (1987). The Type A behaviour pattern and chronic headaches. Behaviour Change, 4(2), 33-39.

Masters, K.S., Lacaille, R., \& Shearer, D.S. (2003). The acute affective response of Type A behaviour pattern individuals to competitive and non-competitive exercise. Canadian Journal of Behavioural Science, 35(1), 25-34.

Mellam, Q.C., \& Espnes, G.A. (2003). Emotional distress and the Type A behaviour pattern in a sample of civil servants. Personality and Individual Differences, 34(7), 1319-1325. 
Moriana, J.A., \& Herruzo, J. (2005). Type A behavior pattern as a predictor of psychiatric sick-leaves of Spanish teachers. Psychological Reports, 96(1), 77-82.

Morrison, K.A. (1997). Personality correlates of the fivefactor model for a sample of business owners/managers: Associations with scores on self-monitoring, Type A behavior, locus of control, and subjective well-being. Psychological Reports, 80, 255-272.

Nabi, H., Consoli, S.M., Chastang, J.F., Chiron, M., Lafont, S., \& Lagarde, E. (2005). Type A behaviour pattern, risky driving behaviours, and serious road traffic accidents: A prospective study of the GAZEL cohort. American Journal of Epidemiology, 161(9), 864-870.

Nakano, K., \& Kitamura, T. (2002). The relation of the anger subcomponent of Type A behavior to psychological symptoms in Japanese and foreign students. Japanese Psychological Research, 43(1), 50-54.

Norden, B. (1995). Type A components, perceived control and related outcomes. Master's dissertation. Johannesburg: University of the Witwatersrand

Northam, S., \& Bluen, S.D. (1994). Differential correlates of components of Type A behaviour. South African Journal of Psychology, 24(3), 131-137.

Nowack, K.M. (1987). Health habits, Type A behaviour and job burnout. Work and Stress, 1(2), 135-142.

Omura, K., Saito, Y., \& Sasaki, Y. (2005). Psychophysiological effects of autogenic training on Type-A behavioral pattern. Japanese Journal of Autogenic Therapy, 24(1/2), 46-57.

Pace, L.A., Suojanen, W.W., Bessinger, R.C., Lee, H., Frederick, R.P., \& Miller, R.E. (1986). Type A manager as addict. Employee Assistance Quarterly, 2(2), 47-63.

Palmero, F., Diez, J.L., \& Asensio, A.B. (2001). Type A behavior pattern today: Relevance of the JAS-S factor to predict heart rate reactivity. Behavioral Medicine, 27(1), 28-36.

Price, V.A. (1982). Type A behavior pattern: A model for research and practice. New York: Academic Press.

Rapport, N.B., McAnulty, D.P., \& Brantley, P.J. (1988). Exploration of the Type A behavior pattern in chronic headache sufferers. Journal of Consulting and Clinical Psychology, 56(4), 621-623.

Robinson, P.B., Stimpson, D.V., Huefner, J.C., \& Hunt, K.N. (1991). An attitude approach to the prediction of entrepreneurship. Entrepreneurship: Theory and Practice, 15(4), 13-31.

Roodt, G., Bester, C.L., \& Boshoff, A.B. (1994). Die graad van werkbetrokkenheid: 'n Bipolêre kontinuum? Journal of Industrial Psychology, 20(4), 12-16.

Roskies, E. (1987). Stress management for the healthy Type A. New York: Guilford Press.

Roskies, E. (1990). Type A intervention: Where do we go from here? Journal of Social Behavior, 5(1), 419-438.

Schein, E.H. (1978). Career dynamics: Matching individual and organizational needs. Boston: Addison-Wesley.

Schein, E.H. (1995). Career orientations inventory. Englewood Cliffs: Prentice Hall.

Schein, E.H., \& Kommers, D.W. (1972). Professional education New York: McGraw-Hill.

Schepers, J.M. (1995). Locus of control inventory. Unpublished report, Johannesburg.

Sebregts, E.H.W.J., Falger, P.R.J., Appels, A., Kester, A.D.M. \& Bär, F.W.H.M. (2005). Psychological effects of a short behavior modification program in patients with acute myocardial infarction or coronary artery bypass grafting: A randomized controlled trial. Journal of Psychosomatic Research, 58(5), 417-424.

Sehgal, M. (2000). Anger, anxiety and Type A behaviour as determinants of essential hypertension and coronary heart disease. Journal of the Indian Academy of Applied Psychology, 26(1/2), 33-39.

Seligman, M.E.P. (1998). Learned optimism. New York: Pocket Books.

Siu, O., Cooper, C.L., \& Leung, T. (2000). Three-wave trend study of managerial stress in Hong Kong: The role of Type A behavior and exercise. International Journal of Stress Management, 7(2), 153-157.

Søgaard, Q.J., Dalgard, O.S., Holme, I., Røysamb, E., \& Håheim, L.L. (2008). Associations between Type A behaviour pattern and psychological distress. Social Psychiatry E Psychiatric Epidemiology, 43(3), 216-223.

Spangenberg, J.J., Shuda, S., \& Robbertze, U.C. (1997). Type A behaviour and hostility in final-year South African students. South African Journal of Psychology, 27(1), 30-36.

Spector, P.E., \& O'Connel, B.J. (1994). The contribution of personality traits, negative affectivity, locus of control and Type A to the subsequent reports of job stressors and job strains. Journal of Occupational and Organizational Psychology, $67,1-4$.

Spence, J.T., Helmreich, R.L., \& Pred, R.S. (1987). Impatience versus achievement strivings in the Type A pattern: Differential effects on students' health and academic achievement. Journal of Applied Psychology, 72(4), 522-528.

Stake, J.E. (1994). Development and validation of the six-factor self-concept scale for adults. Educational and Psychological Measurement, 54(1), 56-72.

Stout, C.W., \& Bloom, L.J. (1982). Type A behavior and upper respiratory infections. Journal of Human Stress, 8(2), 4-7.

Strümpfer, D.J.W. (1980). Higher level manpower shortage, stress and coronary heart disease. South African Mechanical Engineer, 30, 2-21.

Strümpfer, D.J.W. (1990). The distribution of the Type A behaviour pattern in a South African financial institution. Cape Town University of Cape Town.

Strümpfer, D.J.W. (1993a). An overview of Jenkins survey data in South Africa. South African Journal of Psychology, 23(3), $134-144$

Strümpfer, D.J.W. (1993b). The validity of the Jenkins activity survey in terms of illness and work. South African Journal of Psychology, 23(3), 120-131

Suls, J., \& Sanders, G.S. (1989). Type A behavior as a general risk factor for physical disorder. Journal of Behavioral Medicine, 11(3), 201-226.

Sumi, K. (1998). Type A behavior, social support, stress and physical and psychological well-being among Japanese women. Psychological Reports, 83(2), 711-717.

Thoresen, C.E., Friedman, M., Powell, L.H., Gill, J.J., \& Ulmer, D. (1987). Altering the Type A behaviour pattern in postinfarction patients. In D.S. Krantz \& J.A. Blumenthal (Eds.), Behavioural assessment and management of cardiovascular disorders (pp. 97-115). Sarasota: Professional Resource Exchange.

Van Wyk, R. (1998). The Type A behaviour pattern in professionals. Doctoral dissertation. Pretoria: University of Pretoria.

Van Wyk, R., \& Boshoff, A.B. (2000). The relationships of Type A behaviour, organisational and personality variables in pharmacists and accountants: A further analysis. South African Journal of Economic and Management Sciences, 3(2), 189-211.

Van Wyk, R., \& Boshoff, A.B. (2004). Entrepreneurial attitudes: A distinction between two mutually exclusive groups on the Holland hexagon of occupations. South African Journal of Business Management, 35(2), 33-37.

Van Wyk, R., Boshoff, A.B., \& Bester, C.L. (1999). Correlates of Type A behaviour in professionals. South African Journal of Economic and Management Sciences, 2(2), 315-334.

Van Wyk, R., Boshoff, A.B., \& Owen, R. (1999). Monograph: Factor structure and internal validity of psychometric instruments developed in the USA among professionals in South Africa. South African Journal of Economic and Management Sciences, SS1(November), S1-S72.

Webster, S. (1994). Type A behaviour, values and coronary heart disease. Master's dissertation. Johannesburg: Rand Afrikaans University.

Williams, R., Barefoot, J.C., Haney, T.L., \& Harrell, F.E. (1988) Type A behavior and angiographically documented coronary therosclerosis in a sample of 2289 patients. Psychosomatic Medicine, 50(2), 139-152.

Williams, R.B., Barefoot, J.C., \& Schneiderman, N. (2003) Psychosocial risk factors for cardiovascular disease: More than one culprit at work. Journal of the American Medical Association, 290(16), 2190-2193.

Wolf, T.M., Hunter, S., Webber, L.R., \& Berenson, G.S. (1981). Selfconcept, locus of control, goal blockage, and coronary-prone 
behavior pattern in children and adolescents: Bogalusa heart study. The Journal of General Psychology, 105, 13-26.

Yan, L.L., Liu, K., Matthews, K.A., Daviglus, M.L., Ferguson, T.F., \& Kiefe, C.I. (2003). Psychosocial factors and risk of hypertension: The coronary artery risk development in young adults (CARDIA) study. Journal of the American Medical Association, 290(16), 2138-2150.

Yoshimasu, K., Liu, Y., Kodoma, H., Sasazuki, S., Washio, M., Tanaka, K. et al. (2000). Job strain, Type A behavior pattern, and the prevalence of coronary atherosclerosis in Japanese working men. Journal of Psychosomatic Research, 1, 77-83.
Yoshimasu, K., Washio, M., Tokunaga, S., Tanaka, K. Kiu, Y., Kodoma, H. et al. (2001). Relation of Type A behavior pattern and job-related psychological factors to nonfatal myocardial infarction: A case-control study of Japanese male workers and women. Psychosomatic Medicine, 63(5), 797-804.

Yoshimasu, K., Washio, M., Tokunaga, S., Tanaka, K., Liu, Y., Kodama, H. et al. (2002). Relation between Type A behaviour pattern and the extent of coronary atherosclerosis in Japanese women. International Journal of Behavioural Medicine, 9(2), 77-93. 